\title{
Trust In Personal And Impersonal Forms Its Antecedents And Consequences: A Conceptual Analysis Within Organizational Context
}

\author{
Masoodul Hassan, Istanbul University Avcılar Campus, Turkey
}

Fatih Semerciöz, Istanbul University Avcılar Campus, Turkey

\begin{abstract}
Although Mayer et al.'s (1995) integrative model of organizational trust has clarified some confusion regarding the concept of interpersonal trust involving two specific parties by differentiating between factors that cause trust, trust itself, and outcomes of trust through 1) it defined trust as the willingness of a party to be vulnerable to the actions of another party,2) trust is in turn influenced by a trustor's propensity to trust, the trustor's perceived characteristics of a trustee (e.g., trustworthiness of trustee based on his/her ability, benevolence, and integrity), 3) the trust leads to actual risk taking in a relationship since behavioral trust is the assuming of risk, and 4), the desired outcome results from the result of risk taking. But researchers like Luhman (1979), McCauley \& Kuhnert (1992), Zaheer et al.(1998), Costigan et al.(1998), McKnight et al.(1998,2002), and Atkinson and Butcher( 2003) are of the view that root of trust lies in individual relationships is not in opposition to the experience of trust both inside interpersonal relationships and as an institutional phenomenon beyond interpersonal relationships. Moreover, Colquitt et al.(2007) investigated, it remains unclear that which trust antecedents have the strongest relationships with trust whether trust fully mediates the effects of trustworthiness and trust propensity on behavioral outcomes, and do trust relationship vary according to whether the trustee is a leader versus a coworker? Therefore, the aim of this conceptual paper is to investigate the phenomenon of trust in its personal and impersonal forms i.e., interpersonal and institutional(organizational) trust with multiple foci i.e. coworkers, supervisor, and institution(organization) through addressing threefold agenda; (1) to explore the concept of trust by distinguishing its antecedents i.e., trustor's propensity to trust, the trustor's perceived characteristics of a trustee, and institutional trust from trust, (2) to explore whether trust fully mediates the effects of trustworthiness, trust propensity, and institutional trust on behavioral outcomes such as organizational commitment, organizational citizenship behavior, and employees task performance, and (3) to explore that do trust relationships vary according to whether the trustee is a supervisor/leader versus a coworker.
\end{abstract}

Keywords: Organizational Trust, Interpersonal Trust, Trust, Institutional Trust, System Trust, Impersonal trust, Organizational citizenship behavior, Organizational commitment, Employees’ performance

\section{INTRODUCTION}

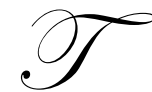

oday's environment is featured as:1) globalization-moving from local economies to worldwide economies-, 2) diversity- more diverse workplaces and markets-, 3) flexibility-fewer rules and procedures, more need for flexible work forces-, 4) flattened structure-less management, more worker empowerment-, and 5) networks-new information technology has enabled more strategic alliances, direct communication- (Adams et al., 2008). In response to this, "trust" as a hallmark of effective organizations (Argyris, 1962; Likert, 1967; McGregor, 1967; Ouchi,1981) has attracted enormous interest of variety of perspectives (Arrow, 
1974; Lindskold, 1978; Gambetta, 1988; Coleman, 1990; Kramer \& Ibsen, 1994; Berscheid, 1994; Bies et al., 1995; Hosmer, 1995; Kramer \& Tyler, 1996; Bigley \& Pearce,1998; Rousseau et al.,1998; Kramer, 1999) including social sciences as shown by special issues on trust in the Academy of Management Review (1998), organizational Science (2003), International Journal of Human Resource Management (2003), and collections of other authoritative papers and surveys on trust. For example, as per Watson Wyatt survey (2002), total return to shareholder (TRS) over a three-year period was $186 \%$ higher for those companies that had high levels of trust compared to those with low levels of trust. Further, researchers have found that trust has been regarded as a major construct in research predicting individual-level \& organizational-level outcomes such as job satisfaction, organizational citizenship behaviors, organizational commitment, turnover, and job performance, employee productivity, team performance, innovative behaviors, workplace behaviors, counterproductive behaviors, organizational revenue and profit (Deluga, 1995; Dirks \& Ferrin, 2001; Flaherty \& Pappas, 2000; Robinson, 1996; Dirks, 2000; Dirks \& Ferrin, 2002; Frenke \& Orlitsk, 2005; Mayer \& Gavin, 2005; Tan \& Tan, 2000; Wat \& Shaffer, 2005; Davis, Schoorman, Mayer, \& Tan, 2000; Simons et al., 2002; Roy et al. 2006; Colquitt, et al.,2007).

Despite, the above positive role of trust within organizations, and progress made by multidisciplinary perspective of trust towards trust literature, however, there appears to be equally widespread lack of agreement on a suitable definition of the concept of trust (Hosmer, 1995). In this regard, Colquitt et al.(2007) provided examples of incongruities on concept of trust such as: 1) behavioral intention (Mayer et al.,1995; McKnight et al., 1998; Rousseau et al.,1998), 2) an internal action, similar to choosing, judging, or preferring (e.g., Lewis \& Weigert, 1985; Riker, 1971), 3) a synonym for trustworthiness i.e., personal characteristics that encourage positive expectations on the part of other individuals (e.g., Butler \& Cantrell, 1984; McKnight et al., 1998), 4), a personality trait that build up early in life and remains relatively stable through maturity (Rotter, 1967; Webb \& Worchel, 1986), 5) a synonym for cooperation or risk taking (e.g., Kee \& Knox, 1970; Lewis \& Weigert,1985; Zand, 1972), and 6) cooperative choices in a dilemma game (e.g., Deutsch, 1958, 1960). Within organizational context, many scholars argued that prior research (Dirks \& Ferrin, 2002; Ferres et al., 2004; McAllister, 1995, Schoorman, Mayer, \& Davis, 1996; Spreitzer \& Mishra, 1999) has recognized and drawn a distinction regarding multiple foci of trust, but, it remains an empirical questions whether there are differences in trust relationships and its specific meaning when it exists between co-workers, leaders and followers, employers and employees, between different organizations or towards an institution (Colquitt et al., 2007; Möllering et al., 2004), but, little research has been conducted on trust in coworkers (Bagraim, 2007). Further, Dirks \& Ferrin (2001) provided that 'the effects of trust on workplace outcomes are less consistent than might be expected as for some work-related outcomes; studies have revealed significant effects of trust whereas others have not'.

Given the multidimensional nature of "trust" 'an employee may trust his coworkers but distrust his supervisor or top management' (McCauley \& Kuhnert,1992:269), therefore, trust exists in both impersonal and personal forms (Atkinson and Butcher, 2003), and this impersonal trust may be named as institutional trust and in a global and highly competitive environment interpersonal trust whether among peers or between employees and their supervisor may also fail, which could result in organizational inefficiency and therefore, future organizations will have to rely both on interpersonal and impersonal type of trust and will have need of complementary mechanisms that support knowledge creation and transfer and as a result role of institutional trust is likely to be complementary to that of interpersonal organizational trust (Ellonen et al., 2008). However, Ellonen et al.(2008) found that institutional trust has been studied very little in the organizational context, with the exceptions of McCauley and Kuhnert (1992), Atkinson and Butcher (2003), Costigan et al. (1998) and McKnight et al. (1998, 2002).

In sum, "trust" is 'something that we feel we need to discuss, perhaps in order to understand it better, but probably also with a view to increasing the chances of maintaining and repairing it wherever it is essential, or at least desirable' (Möllering et al., 2004:557). Therefore, the aim of this conceptual paper is to investigate the phenomenon of trust in its personal and impersonal forms i.e., interpersonal and institutional (organizational) trust with multiple foci i.e. coworkers, supervisor, and institution(organization) through addressing threefold agenda; (1) to explore the concept of trust by distinguishing its antecedents i.e., trustor's propensity to trust, the trustor's perceived characteristics of a trustee, and institutional trust from trust, (2) to explore whether trust fully mediates the effects of trustworthiness, trust propensity, and institutional trust on behavioral outcomes such as organizational commitment, organizational citizenship behavior, and employees task performance, and (3) to explore that do trust relationships vary according to whether the trustee is a supervisor/leader versus a coworker. 
In the section to follow, literature review regarding the concept of trust, facets of interpersonal and institutional trust, antecedents of trust and its multiple foci as put forth by research scholars will be examined. Then, in light of prior research, proposed hypotheses of the study in shape of organizational trust and its effects will be suggested. Finally important of context, measurement implications and summary with conclusion will be presented.

\section{CONCEPTUALIZATION OF TRUST}

Merriam-Webster on line dictionary defined trust as an assured reliance on the character, ability, strength, or truth of someone or something. Thus, according to this definition trust can be approached in both forms i.e., personal and impersonal forms. Möllering et al. (2004) provided that the word "trust" dates back to 13th century Middle English and has its etymological roots in older expressions indicating faithfulness and loyalty, however the phenomenon of trust is probably as old as the earliest forms of human society e.g., Confucius (551-479 BC) had regarded trust to be a prerequisite and basis for all valuable social relations. The concept of trust in philosophic ethics is the result of a given decision or action that recognizes and protects the rights and interests of other people through an application of the ethical principles of analysis (Hosmer, 1995). Watson (2005) provided that however, aside from its importance throughout history, trust has received relatively little research attention until recently (Rousseau et al., 1998), reviewed differently by different fields of scholars in shape of "meso" concept, integrating microlevel psychological processes and group dynamics with macrolevel institutional arrangements, and therefore, a single widely accepted definition of trust has yet to emerge in the literature (Bagraim \& Hime, 2007). As a result, concept of trust has been approached from various theoretical frameworks (see e.g. Cruz and Costa-Silva 2004; Rousseau et al.1998), such as (1) transaction cost theory, where economists have a tendency to analyze trust as either calculative (Williamson, 1975) or institutional (North, 1990), (2) social exchange theory (Blau, 1964) where sociologists conceptualize trust in socially embedded properties of relationships among people or institutions (Granovetter, 1985; Zucker, 1986), (3) agency theory (Eisenhardt, 1989) where trust reduces complexity and insecurity while excluding opportunistic behavior beforehand (Picot et al., 2008), (4) the resource-based view of the firm (Barney, 1991) where trusted human resources provide competitive advantage (Dess et al., 2006), (5) system theory (Luhmann, 1979) where a person can have trust in the working of a system, and (6) attribution theory (Kelley, 1967) where psychologists view trust in terms of attributes of trustors and trustees and focus upon a host of internal cognitions that personal attributes yield (Rotter, 1967; Tyler, 1990; and Deutsch, 1962). Our focus here is exclusively with trust within organizations i.e. as an intra-organizational phenomenon, such as between employees and supervisor/manager or among co-workers (see e.g., Dietz \& Hartog, 2006) where institutional trust is likely to be complementary and positively relate to that of interpersonal organizational trust (see e.g., McKnight et al. 1998, 2002; Ellonen et al., 2008).

\section{INTERPERSONAL TRUST}

Hosmer (1995) regarded Zand (1972) as one who expanded his first definition of trust from the confident expectations of a single individual to approach the dependent interactions of a dyad by defining trusting behavior as consisting of actions that (1) increase one's vulnerability, (2) to another whose behavior is not under one's control, (3) in a situation in which the penalty (disutility) one suffers if the other abuses that vulnerability is greater than the benefit (utility) one gains if the other does not abuse that vulnerability. Without vulnerability, trust is unnecessary because outcomes are unimportant for the trustor and state of being vulnerability implies that as a result of trusting behavior, there is something of importance to be lost or where the potential for loss exceeds the potential for gain (Mayer et al., 1995; Mishra, 1996), thus making oneself to vulnerable is equal to taking risk but according to Mayer et al. (1995) trust is not taking risk per se but rather it is a willingness to take risk and defined trust as 'the willingness of a trustor to be vulnerable to the actions of a trustee based on the expectation that the trustee will perform a particular action important to the trustor, irrespective of the ability to monitor or control that other party'. Thus, according to Mayer et al. (1995), there is no risk taken in the willingness to be vulnerable (i.e., to trust), but risk is inherent in the behavioral manifestation of the willingness to be vulnerable and one does not need to risk anything in order to trust; however, one must take a risk in order to engage in trusting action, so difference between trust and trusting behaviors is between a "willingness" to assuming risk and actually "assuming" risk, therefore trust is the willingness to assume risk; behavioral trust is the assuming of risk. In the same manner, Rousseau et al. (1998) have put the trust as 'a psychological state comprising the intentions to accept vulnerability based on positive expectations of the actions of the trustee'. Colquitt et al.(2007) have provided that both Mayer et al.'s (1995) and 
Rousseau et al.'s (1998) definition of trust attempted to clarify the confusion regarding the definition of trust by differentiating its two main components: (1) intention to accept vulnerability, and (2) positive expectations of the actions of the trustee incorporated in earlier conceptualizations of trust (e.g., Boon \& Holmes, 1991; Cook \& Wall, 1980; Golembiewski \& McConkie, 1975; Read, 1962; Roberts \& O'Reilly, 1974; Barber, 1983). In the same way, McAllister (1995) put interpersonal trust as 'the extent to which a person is confident in, and willing to act on the basis of, the words, actions, and decisions of another' and identified two kinds or bases of trust i.e., (1) cognitive judgments of another's competence or reliability referred to as cognition-based trust, and (2) affective bonds among individuals referred to as affect-based trust. In the same pattern, McKnight, et al. (1998) has defined interpersonal trust as 'one party's willingness to depend on the other party with a feeling of relative security even though negative consequences are possible'. Mishra (1996) put the trust as 'one party's willingness to be vulnerable to another party based on the belief that the latter party is 1) competent, 2) open, 3) concerned, and 4) reliable'. So our conceptualization regarding interpersonal trust reflects the distinction between three necessary constituent parts: (1) as an expectation, (2) a willingness to be vulnerable and (3) a risk-taking act (Dietz and Hartog, 2006).

\section{INSTITUTIONAL OR SYSTEM TRUST}

In order to increase trust within today's dynamic organizations, it is important to realize the dual nature of trust i.e. personal and impersonal forms of trust. As discussed above, McCauley \& Kuhnert (1992) put trust as a multidimensional variable by explaining that an employee may trust his coworkers but distrust his supervisor or top management. They made the distinction between vertical and lateral trust where former refers to trust relations among peers (or equals) who share a similar work situation, whereas the latter refers to trust relations between individuals and either their immediate supervisor, top management or the organizations as a whole. Further, McCauley \& Kuhnert (1992) by referring reciprocal property of trust highlighted by Fox $(1974,1985)$ stated that if the structures, roles, and climate of the organization communicate a lack of trust in employees by top management, employees will respond with distrust and conversely, if top management communicates a high level of trust to its employees, employees will respond with high levels of trust in management, therefore the role of top management involves the creation and management of a system conducive to trust referred by Fox's (1974, 1985) as "institutionalized" trust which does not refer to degrees of trust or distrust that are embodied in personal attitudes between individuals. In other words, interpersonal and institutional (system) trust do not stand alone, but act in concert with one another (Straiter, 2005) in the fact that the root of trust lies in individual relationships is not in opposition to the experience of trust both inside interpersonal relationships and as an institutional phenomenon beyond interpersonal relationships, therefore, we contend that trust exists in impersonal and personal forms (Atkinson and Butcher, 2003). Shamir \& Lapidot (2003) stated that in contrast with interpersonal trust, institutional trust emphasizes the systemic level of trust that enables the maintenance of social order within the system (Luhman, 1979), therefore termed as impersonal in two senses: 1) it is trust in systems or institutions rather than in specific individuals, and, 2) unlike interpersonal trust, it is often not based on the personal experience of the trustor. Shamir \& Lapidot (2003) further argued that trust in organizations often combines both systemic and interpersonal considerations that affect each other and full understanding of systemic trust is not possible without reference to the individuals who are members of the system, and a full understanding of personal trust is not possible without understanding the systemic context in which such personal trust (or distrust) develops (Grey and Garsten, 2001). Straiter (2005) found that Luhmann (1979) was among first who posited that trust occurs within a framework of interaction which is influenced by both personality and social system, and cannot be exclusively associated with either and argued that personal trust and systems trust rest on different bases, the former involves an emotional bond between individuals, and the emotional pain that each would experience in the event of betrayal serves as the protective base of trust, and in case of latter, this emotional content is largely absent in systems trust that is activated by the appearance that "everything seems in proper order" (Lewis \& Weigert, 1985, p. 974). In the same account, Zaheer et al. (1998) recognized trust at both the systemic and the interpersonal level and further explained the importance that how trust translates from the individual level to the organizational level and from the organizational level to the individual level. Shamir \& Lapidot (2003) argued that trust in formal leaders is likely to be affected by both systemic considerations, because such leaders represent the organization or the system in the eyes of their subordinates, and interpersonal considerations arising from the interactions between leaders and subordinates, and thus, the two bases of trust are likely to affect each other. Systemic trust might affect trust in particular leaders, and trust in particular leaders might influence systemic trust. McKnight et al. (1998) termed this impersonal form of trust as institution based trust is defined as "the belief that proper impersonal structures are in place to enable one to 
anticipate a successful future endeavor" such as: 1) structural assurance in shape of safeguards as regulations, guarantees, or contracts are in place to promote success, and 2) situation normality i.e., environment is in proper order and success is likely because situation is normal or favorable within the attributes of competence, benevolence, and integrity of management or organization to promote success (McKnight et al. 1998, 2002). According to Ellonen et al. (2008), this institutional trust could be characterized as the trust of its members in the organization's vision and strategy, its technological and commercial competence, its fair processes and structures, as well as its HR policies, and this impersonal trust is based on the roles, systems and reputations from which inferences are drawn about the trustworthiness of an individual, and its success is determined by the efficiency and the fairness of the organization-wide systems, such as the HR policies (Costigan et al., 1998).

As this, paper incorporates both interpersonal and institutional trust, consistent with Rousseau et al. (1998), Mayer et al. (1995), Mishra (1996), McKnight et al. (1998, 2002) and Ellonen et al. (2008), we define organizational trust as a psychological state comprising the intention to accept vulnerability based on positive expectations individuals have about the ability, benevolence and integrity of organizational members and organization as a whole in shape of institutional trust.

\section{ANTECEDENTS OF TRUST}

In the next section we will discuss about the antecedents of trust i.e., propensity to trust, characteristics of trustee (ability, benevolence, and integrity) upon which intention to accept vulnerability and positive expectations of the actions of someone (coworkers, supervisor) or something (institution) are based.

\subsection{Trustor's propensity to trust}

According to Mayer at al. (1995), traits of the trustor will affect the trust one party has for another is a personality trait or is referred as propensity to trust that leads to a generalized expectation about the trustworthiness of others is proposed to be stable within trustor, however, people differ in their inherent propensity to trust due to different development experiences, personality types, and cultural background (Rotter, 1967). In the same manner, Kramer (1999) put propensity to trust as general predisposition to trust and termed it as people's beliefs about human nature that people extrapolate from their early trust-related experiences and that eventually assumes the form of a relatively stable personality characteristic. McKnight et al. (1998) provided that person has dispositional trust if $\mathrm{s} / \mathrm{he}$ has a consistent tendency to trust across a broad spectrum of situations and persons and is based on two types of reasons: 1) that one assumes that others are generally trustworthy people--hence, one should usually trust others, and 2) that one assumes that irrespective of whether people are good or not, one will obtain better outcomes by trusting them--hence, one should trust them. Chughtai and Buckley (2008) provided that individuals with a high propensity to trust believe that most people are sincere, fair and have good intentions, while on the other hand, people who have a low propensity to trust, see others as self-centered, cunning and potentially dangerous.

\subsection{Trustor's perceived characteristics of a trustee: Ability, Benevolence, and Integrity}

McAllister (1995) argued that 'trust is cognition-based in that we choose whom we will trust in which respects and under what circumstances, and we base the choice on what we take to be 'good reasons,' constituting evidence of trust worthiness'. Mayer et al. 1995 found, although prior researchers have found conditions that lead to trust are ranged to one trustee characteristics to as many as 10 characteristics e.g. availability, competence, consistency, discreetness, fairness, integrity, locality, openness, promise fulfillment, receptivity, trustworthy intentions, ability, motives, benevolence, honesty, judgment, and group goal, but three characteristics of a trustee i.e., ability, benevolence and integrity appear often and explain a major portion of trustworthiness and each contribute a unique perceptual perspective from which to consider the trustee. McKnight et al. (1998) provide that beliefs about the other person's trustworthiness include belief that the other person possesses such attributes as benevolence, honesty, competence, and predictability and further propose that such beliefs form the core cognitive concept that is manifest in intentions to trust, which in turn are manifest in trusting behaviors. By following Mayer et al. (1995), in this paper, in the next section, we will examined the perceived factors of trustworthiness e.g. ability, benevolence, and integrity. 
International Journal of Management \& Information Systems - Second Quarter $2010 \quad$ Volume 14, Number 2 4.2.1. Ability

Mayer et al. (1995), regarding one factor of trustworthiness i.e., ability provide that it highlights the task and situation-specific construct having specific domain of group of skills, competencies, and characteristics that enable a party to have influence in some specific area. Trustee may be highly competent in some area and may not be in other and this specific domain of ability have used by researchers with several synonyms such as competence, perceived characteristic of the trustee, expertness, functional/specific competence, interpersonal competence, business sense and judgment. As a result, trust is domain specific mean that a person may be competent in specific area can be trusted in that specific area. McAllister (1995) also provided that past measures of trust in organizational settings suggest that competence and responsibility are central elements. Mishra (1996) named this antecedent of trust as competence and provided that in organizational setting, managers develop relationships with their subordinates and with other managers largely on the basis of trust, where trust is defined in part in terms of competence. Mishra (1996) further provided that Leaders are also characterized by how much their followers trust them to make competent decisions.

\subsubsection{Benevolence}

According to Mayer et al.(1995), trustee has some specific attachment to the trustor is defined as the extent to which a trustee is believed to want to do good to the trustor, aside from an egocentric profit motive. Mayer et al. (1995) explained that benevolence portrays the perception of a positive orientation of the trustee toward the trustor and constructs having similar characteristics to benevolence have been used by researchers as the basis for trust e.g., trustworthiness in terms of the trustee's motivation to lie as high benevolence in relationship is inversely related to motivation to lie, loyalty as the basis of dyadic i.e., one to one trust, and confidence and trust in a leader are influenced in part by the extent to which the leader's behavior is relevant to the individual's needs and desires. Mishra (1996) put benevolence as concern dimension of trust that one party believes it will not be taken unfair advantage of by another through opportunistic behavior and further explains that this concern does not mean the other party lacks any self-interest but such self-interest is balanced by interest in the welfare of others e.g., employees trust top managers in part because they believe that these managers will care about employees' job security, and in response of any organizational change initiated by management, employees evaluate management in terms of whether it can be trusted to be concerned with the employees' own welfare and interests.

\subsubsection{Integrity}

According to Mayer et al. (1995), the relationship between integrity and trust involves the trustor's perception that the trustee adheres to a set of principles that the trustor finds acceptable and issues of consistency of the party's past actions, credible communications about the trustee from other parties, belief regarding trustee's strong sense of justice, and the extent to which the party's actions are congruent with his or her words all affect the extent to which the party is judged to have integrity and constructs similar to integrity have been discussed and used by theorists as antecedent to trust e.g., integrity, consistency, and fairness, character, and integrity, fairness, and openness of management. Mishra (1996) provides that discrepancies between words and action decrease trust, and recognized its importance in terms of reliable and consistency of behavior, and found that judgments about trust in working relationships become specific based on accumulation of interactions, specific incidents, problems, and events. Mishra further provided that 'the trustworthiness of leaders has also been explicitly defined in terms of their reliability and nothing is noticed more quickly -- and considered more significant -- than a discrepancy between what executives preach and what they expect their associates to practice'. These three factors i.e. ability, benevolence, and integrity along with trustor's propensity to trust appear to explain in brief the within-trustor variation in trust for others (Mayer et al. 1995).

\section{MULTIPLE FOCI OF INTERPERSONAL TRUST AT WORK}

Yang (2005) contended that in any organization, there is more than one focus or referent to which members can attach their trust e.g., coworkers, supervisor, or top management, therefore, a clear depiction of trust referents facilitates the formulation of hypotheses pertaining to relations between trust and other organizational phenomenon (Clark \& Payne, 1997). Möllering et al. (2004) recognized the importance to specify the referents i.e., trustors and the trustees in research on trust by stating that 'it should make a difference, for example, if we ask these questions 
about a trust relationship between co-workers in a nuclear power station, between a management consultant and his client, or between a bank and its regulatory authority as interpersonal trust is a recognized phenomenon, it is a more debatable issue whether a person can trust an organization or organizations each other' (Blois, 1999; Nooteboom, 2002). Organizations may be seen as "actors", but it is considered a bad practice to treat organizations like persons, i.e. to "anthropomorphize the organization" (Zaheer et al., 1998). Bagraim and Hime (2007) provide that within organizations, there are at least two possible foci for the interpersonal trust of individual employees: their supervisor and their co-workers and this dyadic trust relationship between supervisor and subordinate (Butler \& Cantrell, 1984; Deluga, 1994) have enjoyed more research attention than trust in coworkers. Bagraim and Hime (2007) further provided that trust in the organization is not an interpersonal form of trust but rather a systems form of trust (McCauley \& Kuhnert, 1992; Tan \& Tan, 2000) that derives from structures and processes within the organization such as fairness and perceived organizational support. The focus of this paper is on interpersonal forms of trust (coworkers trust and trust in supervisor) along with institutional trust.

\section{HYPOTHESES OF THE CONCEPTUAL STUDY}

\subsection{Perceived Trustworthiness of the Coworkers as an Antecedent of Trust in Coworkers}

Ferres et al. (2004) contend that trust in co-workers concerns confidence that one's colleagues are competent and will act in a fair, reliable and ethical manner, it assumes that co-workers will support their peers and will not take advantage of them by withholding information, consequently co-worker trust also leads employees to act on the basis that they have faith in the words and actions of their peers. So our hypotheses regarding trust in coworkers are as follows:

Hypothesis 1a: The employees' perception of perceived trustworthiness of their coworkers' ability is proposed to relate positively to employees' trust in their coworkers.

Hypothesis 1b: The employees' perception of perceived trustworthiness of their coworkers' benevolence is proposed to relate positively to employees' trust in their coworkers.

Hypothesis 1c: The employees' perception of perceived trustworthiness of their coworkers' integrity is proposed to relate positively to employees' trust in their coworkers.

\subsection{Perceived Trustworthiness of the Supervisor as an Antecedent of Trust in Supervisor}

Mayer et al.'s (1995) model suggests that trust in supervisor /leader will be a function, in part, of the supervisor/leader's perceived ability, benevolence, and integrity. Put differently, trust in the supervisor/ leader is a product of the leader's behavior (Joseph and Bruce E. Winston, 2004). Dirks and Ferrin (2001) provide that the employees' perceptions that leaders have attributes that promote trust may be important for leader effectiveness (Bass, 1990; Hogan et al., 1994). The result of an empirical study by Moye and Henkin (2005) on 2000 salaried employees at a Fortune 500 manufacturing organization in the USA showed that employees who feel empowered in their work environment tend to have higher levels of interpersonal-level trust in their manager. The study conduct by Wong et al. (2002) showed that there is a direct effect of employees' perception of interactional justice and of trust in supervisor on their loyalty to supervisor, and also confirmed trust in supervisor as a mediating variable between interactional justice and loyalty to supervisor. So our hypotheses regarding trust in supervisor are as follows:

Hypothesis 1d: The employees' perception of perceived trustworthiness of their supervisor's ability is proposed to relate positively to employees' trust in their supervisor.

Hypothesis 1e: The employees' perception of perceived trustworthiness of their supervisor's benevolence is proposed to relate positively to employees' trust in their supervisor.

Hypothesis 1f: The employees' perception of perceived trustworthiness of their supervisor's integrity is proposed to relate positively to employees' trust in their supervisor.

\subsection{Propensity to Trust as an Antecedent of Trust in Coworkers and Supervisor}

According to Mayer et al. (1995), to fully understand the extent to which a person is willing to trust another person, both the trustor's propensity to trust and the trustor's perceptions of the trustee's ability, benevolence, and integrity must be distinguished (Mayer et al., 1995). Considering this, our next hypotheses are: 
Hypothesis 2a: Employees' propensity to trust is proposed to relate positively to employees' trust in their coworkers.

Hypothesis 2b: Employees' propensity to trust is proposed to relate positively to employees' trust in their supervisors.

\subsection{Propensity to Trust as a Moderating Variable}

In addition as discussed earlier propensity to trust affects how a trustor perceives the behaviors of others, in shape of moderating the effects of perceived trustworthiness of trustee on trust in coworkers and employee's trust in their supervisors and considering this we further proposes in this regard:

Hypothesis 2c: Employees' propensity to trust is proposed to moderate the effects of the employees' perception of perceived trustworthiness of their coworkers' ability, benevolence and integrity on employees' trust in their coworkers.

Hypothesis 2d: Employees' propensity to trust is proposed to moderate the effects of the employees' perception of perceived trustworthiness of their supervisor's' ability, benevolence and integrity on employees' trust in their supervisor.

\subsection{Institutional trust as a Moderating Variable}

Institutional trust as defined in theoretical framework is the belief that proper impersonal structures are in place to enable one to act in anticipation of a successful future endeavor. McKnight et al. (2002) provide that disposition to trust (propensity to trust) influences trust in vendors (Gefen, 2000), therefore similarly, disposition to trust (propensity to trust) should positively influence perceptions of the institutional setting. McKnight et al. (2002) further provided that when a situation feels safe, we tend to believe that those in the situation have trustworthy attributes (McKnight et al. 1998), in that case institutional trust is proposed to positively relate not only to trusting intensions but also moderate the effects of perceived trustworthiness of trustee (called it as trusting beliefs by McKnight et al., 2002) on trust. By following this, our study further proposes:

Hypothesis 3 a: Institutional trust is proposed to relate positively to employees' trust in their coworkers

Hypothesis 3 b: Institutional trust is proposed to relate positively to employees' trust in their supervisor.

Hypothesis 3 c: Institutional trust is proposed to moderate the effects of the employees' perception of perceived trustworthiness of their coworkers' ability, benevolence and integrity on employees' trust in their coworkers.

Hypothesis $3 \mathrm{~d}$ : Institutional trust is proposed to moderate the effects of the employees' perception of perceived trustworthiness of their supervisor's ability, benevolence and integrity on employees' trust in their supervisor.

Hypothesis 3 e: Employees' propensity to trust is proposed to relate positively to institutional trust.

\subsection{Effects of Trust - Trust As a Mediating Variable}

As this conceptual study is concentrating on mediating effects of trust on organizational citizenship behavior, organizational commitment, and employees' performance, so we will examine these in the next section, and formulate the research hypotheses.

\subsubsection{Trust and Organizational Commitment}

Organizational commitment reflects a psychological bond that an individual identifies with an organization (Meyer \& Allen, 1991; Meyer \& Allen, 1997), having three components (Meyer and Allen,991) such as normative commitment (the individual's felt obligation to remain in the organization), affective commitment (an individual's emotional attachment and/or identification with the organization), and continuance commitment (individuals need to stay with the organization as they have no other choice or no other desirable options. In the similar way, Mowday et al. (1982) have defined organizational commitment as "the relative strength of an individual's identification with 
and involvement in a particular organization". An empirical study by Laschinger et al. (2000) with a random sample of 412 Canadian staff nurses found that empowered nurses reported higher levels of organizational trust, which in turn resulted in higher levels of affective commitment. In another study by Aryee et al. (2002), argued and confirmed that organizational trust is related to organizational commitment, and mediates the relationship between organizational justice components and organizational commitment. Moreover, study by Chen et al. (2005) revealed that, employees who perceive the organization as demonstrating care and concern will reciprocate this in the form of positive work outcomes, such as organizational citizenship behavior and organizational commitment. Bagraim and Hime (2007) study showed relationship between trust in supervisor and affective commitment to the supervisor, but moderately low relationship between trust in co-workers and affective commitment to co-workers. Keeping in view the positive relationship of trust with organizational commitment we further proposes that:

Hypothesis 4a: Employees' Trust in their coworkers is proposed to mediate the effects of the employees' perception of perceived trustworthiness of their coworkers' ability, benevolence and integrity on employees' organizational commitment.

Hypothesis 4b: Employees' Trust in their supervisor is proposed to mediate the effects of the employees' perception of perceived trustworthiness of their supervisor's ability, benevolence and integrity on employees' organizational commitment.

\subsubsection{Trust and Organizational Citizenship Behavior}

Katz (1964) is the among who first recognize the importance of a class of discretionary and spontaneous behaviors that are beyond explicit role requirements, but that are essential for organizational effectiveness conceptualized by Smith et al. (1983) as "organizational citizenship behavior" (OCB), and then defined by Organ (1988) as "individual behavior that is discretionary, not directly or explicitly recognized by the formal reward system, and that in the aggregate promotes the effective functioning of the organization" (Farh, Zhong and Organ, 2004). Nine major dimensions of OCB have been identified: 1) Altruism (Discretionary behavior that has the effect of helping a specific other person with an organizationally relevant task or problem, 2) Conscientiousness (Discretionary behavior on the part of an employee that goes well beyond the minimum role requirements of the organization, in the areas of attendance, obeying rules and regulations, breaks, and so forth, 3) Sportsmanship (Willingness of employees to tolerate less than ideal circumstances without complaining, 4) Courtesy (Discretionary behavior on the part of an individual aimed at preventing work-related problems with others), 5) Civic virtue (Behavior on the part of individuals indicating that they responsibly participate in, are involved in, or are concerned about the life of the organization, 6) Functional participation (participatory contribution in which individuals focus on themselves rather than others in their organizations e.g., performing additional work activities, volunteering for special assignments, 7) Advocacy participation (behavior targeted at others in an organization and reflecting a willingness to be controversial, such as encouraging quiet people to speak up in meetings and helping coworkers think for themselves, 8) Loyalty (Allegiance to an organization and promotion of its interest), and 9) Voice (promote behavior that emphasizes the expression of constructive challenge intended to improve rather than merely criticize (Farh, Zhong and Organ, 2004). The results of Mayer\& Gavin (2005) study showed that trust in multiple levels of management (top management and plant managers) was positively related to employees' ability to focus on performance, and this ability to focus was positively linked to greater organizational citizenship behaviors. In a study of Chinese workers in joint ventures and state-owned enterprise, conducted by Wong et al. (2006), the results showed that trust in organization was positively related to OCB. In recent study of interpersonal trust by Singh \& Srivastava (2009) provides that interpersonal trust is positively associated with organizational citizenship behavior implying that the development of trust at the interpersonal level may be used as a strategy to motivate the employees to engage in extra role behaviors to ensure improved individual and organizational performance. So we further propose that:

Hypothesis 5a: Employees' Trust in their coworkers is proposed to mediate the effects of the employees' perception of perceived trustworthiness of their coworkers' ability, benevolence and integrity on employees' organizational citizenship behavior.

Hypothesis 5b: Employees' Trust in their supervisor is proposed to mediate the effects of the employees' perception of perceived trustworthiness of their supervisor's ability, benevolence and integrity on employees' organizational citizenship behavior. 
International Journal of Management \& Information Systems - Second Quarter $2010 \quad$ Volume 14, Number 2

\subsubsection{Trust and Employees Performance}

Colquitt et al. (2007) in their meta-analytic study found a positive relationship between trust in leader and task performance, however, the relationship between trust in co-worker and task performance was found to be even greater, finally conclude that trust allows the development of a more effective exchange relationship between the trustor and trustee (Blau, 1964), which facilitates high task performance and positive behaviors on the job. Task performance can be defined as 'the effectiveness with which job incumbents perform activities that contribute to the organization's technical core either directly by implementing a part of its technological process, or indirectly by providing it with needed materials or service' (Borman \& Motovidlo, 1993). Tsui et al.'s1997 study found that employees performed better on core tasks, demonstrated more citizenship behavior, and expressed a higher level of affective commitment to an employer when they worked in an overinvestment (by the employer) or mutual investment relationship than when they worked in a quasi-spot-contract or underinvestment relationship. Dirks and Ferrin (2001), state that two studies did find evidence for a significant, positive main effect of trust on group performance (Dirks, in press; Klimoski \& Karol, 1976) and one study reported a significant positive effect on business unit performance (Davis, Schoorman, Mayer, \& Tan, 2000). Keeping in view the relationship between the trust and employees task performance, we further propose that:

Hypothesis 6a: Employees' Trust in their coworkers is proposed to mediate the effects of the employees' perception of perceived trustworthiness of their coworkers' ability, benevolence and integrity on employees' task performance.

Hypothesis 6b: Employees' Trust in their supervisor is proposed to mediate the effects of the employees' perception of perceived trustworthiness of their supervisor's ability, benevolence and integrity on employees' task performance.

\section{IMPORTANT OF CONTEXT \& MEASUREMENT IMPLICATIONS}

It is critical to differentiate between factors that cause trust, trust itself, and outcomes of trust that must be measured through survey in order to fully test the model, but the specific consequences of trust will be determined by the contextual factors such as stakes involved, the balance of power in the relationship, the perception of the level of risk, alternatives available to the trustor, different places of the dyad within a hierarchical relationship, policies and procedures external to the dyad, prior experiences between the individuals, and perceived similarity between the trustor and trustee. Therefore, more emphasis should be placed on the dynamic nature of trust and the conditions under which the research findings presented (see e.g., Mayer et al., 1995; Burke et al., 2007). This is important, since a failure to account for these may lead researchers to assign too great an effect to the input provided by the trustee, and/or to any trust-influencing independent variable such as an HRM intervention (Dietz and Hartog, 2006).Further in this regard, Colquitt et al. (2007) argue that 'conceptual distinctions are more difficult to maintain in the minds of survey respondents who fill out scales like Mayer and Davis's (1999) e.g., demonstrating caring and concern is a facet of benevolence, whereas a strong sense of justice is a facet of integrity (Mayer \& Davis, 1999; Mayer et al.,1995); however, scholars in the organizational justice literature view caring and concern as a facet of “interactional justice” (Bies \& Moag, 1986), suggesting a blurring of the benevolence-integrity boundary’.

On the subject of the identity of the referent, 'it does remain crucial to be specific about the exact referent or group of referents in the wording of the items, and to remain consistent throughout the items, or to analyze the different relationships separately' (Dietz and Hartog, 2006). Moreover, results of meta analytic study of Colquitt et al. (2007) showed that 'the relationships between trust and its antecedents and consequences did not vary significantly across measures based on the positive expectations or willingness-to-be-vulnerable components of trust definitions (Mayer et al., 1995; Rousseau et al., 1998) or across direct measures that explicitly use the word trust suggests that it may not matter in what sense one trusts'. They further stated that, therefore, 'the most rigorous test of trust measurement effects would involve including positive expectations, willingness to be vulnerable, and direct measures in a single study to see how their zero-order and unique relationships differ from one another'. 
International Journal of Management \& Information Systems - Second Quarter $2010 \quad$ Volume 14, Number 2 8. SUMMARY AND CONCLUSION

In response to changes in the competitive situation, innovation potential of information and communication technology, and value changed in the working world and society, management's key task among others (integration, relationship management) is trust building (Picot et al., 2008). In this conceptual paper, with the help of prior research, we have tried to clarify the conceptual distinctions among trust (the intention to accept vulnerability to a trustee based on positive expectations of his or her actions), perceived factors of trustworthiness (the ability, benevolence, and integrity of a trustee), and trust propensity (a dispositional willingness to rely on others), and institutional trust (is the belief that proper impersonal structures are in place to enable one to anticipate a successful future endeavor in shape of organizational members' trust in the organization's vision and strategy, its technological and commercial competence, its fair processes and structures, as well as its HR policies). After conceptualizing the trust in its both forms i.e. interpersonal and impersonal, we put organizational trust as a psychological state comprising the intention to accept vulnerability based on positive expectations individuals have about the ability, benevolence and integrity of organizational members and organization as a whole in shape of institutional trust.

To obtain the answer of an empirical question whether trust relationships vary when that identifiable party is leader based, coworker based, and or organization, we have examined trust phenomenon between coworkers, between employees and their supervisor, and on institutional level. As trust is regarded as a proximal antecedent of a variety of job performance behaviors; in this conceptual study with the help of prior research, we present these performance behaviors in shape of organizational commitment, organizational citizenship behaviors and employees' task performance. Moreover, attention is drawn to measurement issues related to trust research with the aim that 'researchers may consider alternative research methodologies and leverage the additional insight gained into trust relationships to provide theoretical advances and practical solutions' (Burke et al., 2007).

This conceptual study plays an important contribution to elaborate conceptual positions in the current debate on the role of trust within organizational contexts. For example given the importance of trust to key organizational outcomes, our conceptual study can provide a guide for increasing trust in organizations e.g., ability, benevolence, and integrity provide three distinct avenues for fostering trust, as proved through discussing empirical results, all three were highly correlated with trust and all three had significant, unique relationships with it (see e.g. Colquitt et al., 2007). Further, through operationalizing the constructs proposed in this conceptual study will help to study how organizations can manage in response to growing competitive pressures by viewing individuals or 'human resources' as a more important strategic potential for gaining competitive advantages than traditional factors such as product and process technologies, economies of scale, financial resources or protected and / or regulated markets, so that employees are trusted to carry out their work as a team worker, relationship manager, innovator, subject and method specialist, and entrepreneur in line with the organization's goals and thus feel that their dedication, competence, and creativity are key ingredients in the organization's business success. (See e.g., Picot et al., 2008).However, to materialize all this, we need institutional trust so that when a situation feels safe, we tend to believe that those in the situation have trustworthy attributes, and therefore in this conceptual study, we proposed that institutional trust is positively relate not only to propensity to trust but also moderate the effects of perceived trustworthiness of trustee.

In comparison of Mayer et al.'s (1995) integrative model, our conceptual study proposed to study the phenomenon of trust with its personal and impersonal forms i.e., interpersonal and institutional with multiple foci i.e., coworkers, supervisor, and institution (organization).

Issue that require further analysis is to examine whether the importance of the three trustworthiness facets varies across jobs e.g., ability may be a stronger predictor in jobs that require frequent learning or technical competence (Colquitt et al., 2007), and on the other hand, benevolence and integrity may be stronger predictors in jobs where task interdependence necessitates frequent interactions (Wageman, 2001).

Future research could include selected other factors as antecedents of interpersonal trust (Bijlsma and Koopman 2003) such as transformational leadership, perceived organizational support (Connell et al. 2003), transactional leadership, distributive justice (Dirks and Ferrin 2002), other factors that can include in consequences of interpersonal trust such as absence of monitoring, team satisfaction (Costa 2001), mutual learning (Nonaka and 
Takeuchi, 1995; Boisot, 1995; Bijlsma et al., 1999; Janowicz and Noorderhaven, 2002), and trust and contextual organizational variables such as corporate culture, organizational control systems, organizational poliices, resource allocation, and financial health of the firm (Chan, 1997).

In conclusion, it is hoped that we have not only provided some clarity to constructs commonly examined in trust research but also proposed that trust in organizations, and especially of trust between coworkers, and between leaders and subordinates, should pay more attention to the collective aspects of the phenomenon, and therefore in our theoretical analysis of trust has been extended beyond the current emphasis on interpersonal processes to include institutional considerations.

\section{AUTHOR INFORMATION}

Mr. Masoodul Hassan is a PhD Candidate at Istanbul University, School of Business having scientific areas of interest and international publications in Contemporary Management \& Organization Approaches. His qualifications include: MBA (BZU Pak), Bachelor of Laws (BZU Pak), Fellow in Cost and Management Accountants of Pakistan, Fellow Life Management Institute (LOMA USA), Associate Customer Service (LOMA USA), and Associate Chartered Insurer (CII UK). He has served as Training In charge of Life Insurance Corporation of Pakistan, permanent and visiting faculty member in public universities and professional Institutes of Pakistan and abroad, and Banker at National Bank of Pakistan.

Fatih Semerciöz PhD Associate Professor in Management. Dr. Semerciöz is an academician and research fellow at Istanbul University, School of Business. He has international and national publications in the field of organization and management issues. His research fields; trust, inter-organizational relations, industrial districts, strategic alliances, family business. He has worked as a visiting scholar at Youngstown State University (USA) and De Montford University (England) as part of an exchange programs. He teaches introduction to business, management and organization, inter-organizational relations and trust, strategic management and international management at Istanbul University as well as at privately established academic institutions.

\section{REFERENCES}

1. Argyris, C. (1962). Interpersonal competence and organizational effectiveness. Homewood, IL: Dorsey.

2. Atkinson, S. and Butcher, D. (2003), "Trust in managerial relationships", Journal of Managerial Psychology, Vol.18 No. 4,. 282-304.

3. Arrow, K. (1974). The limits of organization. New York: Norton.

4. Adams, B.D., Michael H. Thomson, Andrea Brown, Jessica A. Sartori, Tamsen Taylor, and Sonya Waldherr (2008). Organizational Trust in the Canadian Forces. DRDC Toronto No. CR-2008-038

5. Berscheid, E. (1994). Interpersonal relationships. Annual Review of Psychology, 45, 79-129.

6. Aryee, S., Budhwar, P.S., \& Chen, Z.X. (2002). Trust as a mediator of the relationship between organizational justice \& work outcomes: Test of a social exchange model. Journal of Organizational Behavior, 23, 267-285.

7. Bagraim, J.J. and Hime, P. (2007). The Dimensionality of Workplace Interpersonal Trust and Its Relationship to Workplace Affective Commitment. SA Journal of Industrial Psychology, 33 (3), 43-48

8. Bies, R., B., Sheppard, R. L. (Eds.). (1995). Research on negotiations in organizations. Vol. 5 Greenwich, CT: JAI.

9. Baek-Kyoo (Brian) Joo (2008). The Antecedents and Consequence of Organizational Commitment: The Roles of Organizational Learning Culture, Leader-Member Exchange Quality, and Turnover Intention. Midwest Academy of Management Conference

10. Burke,C.S. Sims, D.E. Lazzara, E.H. \& Salas, E. (2007) Trust in Leadership: A multi-level review and integration. The Leadership Quarterly 18, 606-632

11. Barber, B. (1983). The logic and limits of trust. New Brunswick, NJ: Rutgers University Press.

12. Bies, R. J., \& Moag, J. F. (1986). Interactional justice: Communication criteria of fairness. In R. J. Lucky, B. H. Sheppard, \& M. H. Bazerman (Eds.), Research on negotiations in organizations 1, 43-55. Greenwich, CT: JAI Press. 
13. Barney, J.B.(1991) Firm resources and sustained competitive advantage. Journal of Management.17, 99120.

14. Boon, S. D., \& Holmes, J. G. (1991). The dynamics of interpersonal trust: Resolving uncertainty in the face of risk. In R. A. Hinde \& J. Groebel (Eds.), Cooperation and prosocial behavior (pp. 190-211). Cambridge, England: Cambridge University Press.

15. Bass, B. (1990). Bass \& Stodgill's handbook of leadership. New York: Free Press.

16. Bijlsma, K.M., Prins, E. and Weber, B. (1999), "Managerial perspectives on success and failure of postacquisition processes", in Rahim, A., Golembiewski, R.T. and Mackenzie, K.D. (Eds), Current Topics in Management, Vol. 4, JAI Press, Stamford, CT, pp. 155-79.

17. Blau, P. M. (1964). Exchange and power in social life. New York: Wiley.

18. Blois, K.J. (1999), "Trust in business to business relationships: an evaluation of its status", Journal of Management Studies, Vol. 36 No. 2, pp. 197-215.

19. Borman, W. C., \& Motowidlo, S. J. (1993). Expanding the criterion domain to include elements of contextual performance. In N. Schmitt,W. C. Borman, \& Associates (Eds.), Personnel selection in organizations (pp. 71-98). San Francisco: Jossey-Bass.

20. Boisot, M.H. (1995). "Information Space, a Framework for Learning in Organizations, Institutions and Culture" Routledge, London.

21. Bijlsma, K. \& Koopman, P. (2003), "Introduction: trust within organizations" Free University Amsterdam, The Netherlands Personnel Review Vol. 32 No. 5, pp. 543-555

22. Butler, J.K. (Jnr). \& Cantrell, R.S. (1984). A behavioural decision theory approach to modelling dyadic trust in superiors and subordinates. Psychological Reports, 115, 19-28.

23. Butler, J. K., Jr., Cantrell, R. S., \& Flick, R. J. (1999). Transformational leadership behaviors, upward trust, and satisfaction in self-managed work teams. Organization Development Journal, 17, 13-28.

24. Bigley, G.A. \& Pearce, J.L. (1998). Straining for shared meaning in organization science: Problems of trust and distrust. Academy of Management Review, 23, 405-421.

25. Chughtai, A. A. and Bucley, F. (2008). Work Engagement and its Relationship with State and Trait Trust: A Conceptual Analysis. Institute of Behavioral and Applied Management page 47-71

26. Connell, J., Ferres, N. and Travaglione, T. (2003), "Engendering trust in manager-subordinate relationships: predictors and outcomes", Personnel Review, Vol. 32 No. 5, pp. 569-87.

27. Costa, A.C., Roe, R.A. and Taillieu, T. (2001), "Trust within teams, the relation with performance effectiveness", European Journal of Work and Organizational Psychology, Vol. 10 No. 3, 225-44.

28. Costigan, R.D., Ilter, S.E. and Berman, J.J. (1998), "A multi-dimensional study of trust in organisations", Journal of Managerial Issues, Vol. X No. 3, pp. 303-17.

29. Colquitt, J.A., Scott, B.A. \& LePine, J.A. (2007). Trust, trustworthiness, and trust propensity: A metaanalytic test of their unique relationships with risk taking and job performance. Jour.of Ap. Psychology, 92, 909-927.

30. Cook, J., \& Wall, T. (1980). New work attitude measures of trust, organizational commitment and personal need non-fulfillment. Journal of Occupational Psychology, 53, 39-52.

31. Coleman, J. S. 1990. Foundations of social theory. Cambridge, MA: Harvard University Press.

32. Chan, M. (1997). Some Theoretical Propositions Pertaining to the Context of Trust. The International Journal of Organiational Analysis, Vol.5, No. 3 pp. 227-248

33. Chen, Z.X., Aryee, S., \& Lee, C. (2005). Test of a mediation model of perceived organizational support. Journal of Vocational Behavior, 66, 457-470.

34. Clark, M. C., \& Payne, R. L. 1997. The nature and structure of workers' trust in management.

35. Journal of Organizational Behavior, 18: 205-224.

36. Cruz, J.G. and Costa-Silva, S. (2004), "Trust: theoretical framework and underlying disciplines, conceptualization, antecedents and consequences", paper presented at EURAM -European Academy of Management, St Andrews, Scotland, 5-8 May 2004.

37. Deluga, R. J. 1995. The relation between trust in the supervisor and subordinate organizational citizenship behavior. Military Psychology, 7: 1-16.

38. Dess, G.G., Lumpkin, G.T., \& Taylor, M. (2006). Strategic Management: Creating Competitive Advantages. McGraw Hill College

39. Dirks, K.T. (1999). The Effects of Interpersonal Trust on Work Group Performance. Journal of Applied Psychology, 84, 445-455 
40. Dirks, K. T., \& Ferrin, D. L. (2002). The role of trust in organizational settings. Organization Science, 12, 450-467.

41. Dirks, K.T. (2000). Trust in leadership and team performance: Evidence from NCAA basketball. Journal of Applied Psychology, 85, 1004-1012

42. Dirks, K. T., \& Ferrin, D. L. (2002). Trust in leadership: Meta-analytic findings and implications for research and practice. Journal of Applied Psychology, 87, 611-628.

43. Dirks, K. T., \& Ferrin, D. L. (in press). The role of trust in organizational settings. Organization Science

44. Davis, J. H., Schoorman, F. D., Mayer, R. C., \& Tan, H. H. (2000). The trusted general manager and business unit performance: Empirical evidence of a competitive advantage. Strategic Management Journal, $21,563-576$.

45. Deluga, R.J. (1994). Supervisor trust building, leader-member exchange and organizational citizenship behavior. Journal of Occupational and Organizational Psychology, 64 (4), 316-327.

46. Dietz, G., and Den Hartog. (2006)."Measuring trust inside organizations." Personnel Review, 35(5)557588.

47. Deutsch, M. (1958). Trust and suspicion. Journal of Conflict Resolution, 2, 265-279.

48. Deutsch, M. (1960). The effect of motivational orientation upon trust and suspicion. Human Relations, 13, $123-139$.

49. Ellonen, R. Blomqvist, K. \& Puumalainen, K. (2008).The role of trust in organizational innovativeness. European Journal of Innovation Management Vol. 11 No. 2, 2008 pp. 160-181

50. Eisenhardt, K.M. (1989), "Agency theory: an assessment and review", Academy of Management Review, Vol. 14 No. 1 , pp. $57-71$

51. Ferres, N., Connell, J. \& Travaglione, A. (2004). Co-worker trust as social catalyst for constructive employee attitudes. Journal of Managerial Psychology Vol. 19 No. 6 pp. 608-622

52. Flaherty, K. E., \& Pappas, J. M. 2000. The role of trust in salesperson-sales manager relationships. Journal of Personal Selling and Sales Management, 20: 271-278.

53. Frenkel, S., \& Orlitzky, M. (2005). Organizational trustworthiness and workplace labor productivity: Testing a new theory. Asia pacific journal of Human Resources, 43, 34-51.

54. Farh, J.L. Zhong, C.B. and Organ, D.W. (2004). Organizational Citizenship Behavior in the People's Republic of China. Organization Science Vol. 15, No. 2, pp. 241-253

55. Fox, A. (1974). Beyond contract: Work, Power, and Trust Relations. London: Faber and Faber.

56. Fox, A. (1985). Man Mismanagement, 2nd ed. London: Hutchinson. Friedlander, F. (1970). "The Primacy of Trust as a Facilitator of Further Group Accomplishment." Journal of Applied Behavioral Science 6(4):387-400.

57. Gambetta, D. G. (Ed.), (1988). Trust: Making and breaking cooperative relations. New York: Basil Blackwell.

58. Granovetter, M. 1985. Economic action and social structure: The problem of embeddedness. American Journal of Sociology, 91, 481-510.

59. Gefen, D. (2000). e-Commerce: The role of familiarity and trust. Omega: Internat. J. Management Sci.28(6) 725-737

60. Grey, C., and C. Garsten 2001 'Trust, control and postbureaucracy'. Organization Studies 22: 229-250.

61. Golembiewski, R. T., \& McConkie, M. (1975). The centrality of interpersonal trust in group processes. In C. L. Cooper (Ed.), Theories of group processes (pp. 131-185). New York: Wiley.

62. Hosmer, L. T. 1995. Trust: The connecting link between organizational theory and philosophical ethics. Academy of Management Review, 20, 379-403.

63. Hogan, R., Curphy, G., \& Hogan, J. (1994). What we know about leadership: Effectiveness and personality. American Psychologist, 49, 493- 504.

64. Janowicz, M. and Noorderhaven, N. (2002), "The role of trust in interorganisational learning in joint ventures", Proceedings of EURAM Conference, Stockholm.

65. Joseph, E.E. Winston, B.E. (2005). A correlation of servant leadership, leader trust, and organizational trust.. Leadership \& Organization Development Journal Vol. 26 No. 1, pp. 6-22

66. Kramer, R. M., A. Isen. 1994. Trust and distrust: Its psychological and social dimensions, Motivation and Emotion, 18, 105-107.

67. Kelley, H.H. (1967), "Attribution theory in social psychology", in Levine, D. (Ed.), Nebraska Symposium on Motivation, University of Nebraska Press, Lincoln, pp. 192-238. 
International Journal of Management \& Information Systems - Second Quarter $2010 \quad$ Volume 14, Number 2

68. Kramer, R. M., T. R. Tyler (Eds.). 1996. Trust in organizations: Frontiers of theory and research. Thousand Oaks, CA: Sage Publications.

69. Kramer, R. 1999. Trust and distrust in organizations: Emerging perspectives, enduring questions. Annual Review of Psychology, 50,569-598.

70. Klimoski, R. J., \& Karol, B. L. (1976). The impact of trust on creative problem solving groups. Journal of Applied Psychology, 61, 630-633.

71. Katz, D. 1964. The motivational basis of organizational behavior. Behavioral Sci. 9, 131-146.

72. Kee, H.W., \& Knox, R.E. 1970. Conceptual and methodological considerations in the study of trust. Journal of Conflict Resolution. 14: 357-366

73. Lind, (2001) E.A. Lind, Fairness heuristic theory: Justice judgments as pivotal cognitions in organizational relations. In: J. Greenberg and R. Cropanzano, Editors, Advances in organizational justice, Stanford University Press, Stanford, CA pp. 56-88

74. Lewis, D. J., \& Weigert, A. (1985). Trust as a social reality. Social Forces, 64, 967-985.

75. Lindskold, S. (1978). Trust development, the GRIT proposal, and the effects of conciliatory acts on conflict and cooperation. Psychological Bulletin., 85, 772-793.

76. Laschinger, H.K.S. Finegan, J. Shamian, J. and Casier, S. (2000). Organizational Trust and Empowerment in Restructured Healthcare Settings: Effects on Staff Nurse Commitment. The Journal of Nursing Administration Issue: Volume 30(9), pp 413-425

77. Likert, R. 1967. The human organization. New York: McGraw-Hill.

78. Lee, J.N., Huynh, M.Q. and Hirschheim, R. (2009). Exploring the Role of Initial Trust, Initial Distrust, and Trust through Knowledge Sharing in IT Outsourcing: From a Service Receiver's Perspective. SpringerVerlag Berlin Heidelberg

79. Luhmann, N. (1979), Trust and Power: Two Works by Niklas Luhmann, Wiley, Chichester.

80. McGregor, D. 1967. The professional manager. New York: McGraw-Hill.

81. McAllister, D. J. 1995. Affect- and cognition-based trust as foundations for interpersonal cooperation in organizations. Academy of Management Journal, 38: 24-59.

82. Meyer, J. P., \& Allen, N. J. (1991). A three component conceptualization of organization commitment. Human Resource Management Review, 1(1), 61-89.

83. Meyer, J. P., \& Allen, N. J. (1997). Commitment in the workplace: Theory, research, and application. Thousand Oaks, CA: Sage.

84. Meyer, J. P., Allen, N. J., \& Smith, C. A. (1993).Commitment to organizations and occupations: Extension and test of a three-component conceptualization. Journal of applied psychology, 78(4), 538-551.

85. Mowday, R., Steers, R., \& Porter, L. (1982). Employee-organization linkages: The psychology of commitment, absenteeism, and turnover. New York: Academic Press.

86. Mayer, R. C., Davis, J. H., \& Schoorman, F. D. (1995). An integrative model of organizational trust. Academy of Management Review, 20, 709-734.

87. Mayer, R. C., \& Davis, J. H. (1999). The effect of the performance appraisal system on trust for management: A field quasi-experiment. Journal of Applied Psychology, 84, 123-136.

88. Mayer, R., \& Gavin, M. (2005). Trust in management and performance: Who minds the shop while the employees watch the boss? Academy of Management Journal, 48(5), 874-888.

89. McCauley, D.P. and Kuhnert, K.W. (1992), "A theoretical review and empirical investigation of employee trust in management", Public Administration Quarterly, Vol. 16 No. 2, pp. 265-85.

90. McKnight, D.H., Choudbury, V. and Kacmar, C. (2002), "Developing and validating trust measures for ecommerce: an integrative typology", Information Systems Research, Vol. 13 No. 3, pp. 334-61.

91. McKnight, D.H., Cummings, L.I. and Chervany, N.I. (1998), "Initial trust formation in new organisational relationships", Academy of Management Review, Vol. 23 No. 3, pp. 473-90.

92. Möllering,G., Bachmann, R. \& Lee, S.H. (2004). Understanding organizational trust-foundations, constellations, \&Issues of operationalisation. Journal of Managerial Psychology V. 19 No. 6, pp. 556-570 Moye, M.J. and Henkin, A.B. (2005). Exploring associations between employee empowerment and Interpersonal trust in managers. Journal of Management Development Vol. 25 No. 2, 2006 pp. 101-117 Mishra, A. K. 1996. Organizational responses to crisis: The centrality of trust. In R. M. Kramer \& T. M. Tyler (Eds.), Trust in organizations: Frontiers of theory and research: 261-287. Thousand Oaks, CA: Sage. Nonaka, I. and Takeuchi, H. (1995), The Knowledge-creating Company, Oxford University Press, New York, NY. 
97. Nooteboom, B. (2002), Trust: Forms, Foundations, Functions, Failures and Figures, Edward Elgar, Cheltenham.

98. North, D. and Smallbone, D. (2000), "The innovativeness and growth of rural SMEs during the 1990s", Regional Studies, Vol. 34 No. 2, pp. 145-57.

99. Organ, D.W.1988. Organizational Citizenship Behavior: The Good Soldier Syndrome. Lexington Books, Lexington, MA.

100. Ouchi, W.G.(1981).Theory Z: How American business can meet the Japanese challenge. Reading, MA: Addison-Wesley.

101. Picot, A. Reichwald, R. and Wigand, R.(2008). Information, Organization, and Management. SpringerVerlag Berlin Heidelberg

102. Rousseau, D., Sitkin, S., Burt, R., Camerer, C. 1998. Not so different after all: A cross-discipline view of trust. Academy of Management Review, 23, 387-392.

103. Roy J. Lewicki, Edward C. Tomlinson and Nicole Gillespie (2006). Models of Interpersonal Trust Development: Theoretical Approaches, Empirical Evidence, and Future Directions. Journal of Management 32; 991

104. Ross, W., \& LaCroix, J. (1996). Multiple meanings of trust in negotiation trust, trustworthiness, and trust propensity, theory and research: A literature review and integrative model. International Journal of Conflict Management, 7, 314-360.

105. Robinson, S. L. (1996). Trust \& breach of the psychological contract. Administrative Science Quarterly, 41 574- 599.

106. Riker, W. H. (1971). The nature of trust. In J. T. Tedeschi (Ed.), Perspectives on social power (pp. 63-81) Chicago: Aldine.

107. Roberts, K. H., \& O'Reilly, C. A. (1974). Measuring organizational communication. Journal of Applied Psychology, 59, 321-326.

108. Read, W. H. (1962). Upward communication in industrial hierarchies. Human Relations, 3-16.

109. Rotter, J. B. (1967). A new scale for the measurement of interpersonal trust. Journal of Personality, 35 , 651-665.

110. Simons, T., \& McLean Parks, J. (2002). Empty words: The impact of perceived managerial integrity on employees, customers and profits. Paper presented at the annual meeting of the Academy of Management, Denver, CO.

111. Spreitzer, G.M. \& Mishra, A.K. (2002). To stay or to go: voluntary survivor turnover following an organizational downsizing. Journal of Organizational Behaviour, 23, 707-729.

112. Schoorman, D. F., Mayer, R. C., \& Davis, J. H. (1996, April). Empowerment in veterinary clinics: The role of trust in delegation. Paper presented at the annual meeting of the Society of Industrial and Organizational Psychology, San Diego, CA.

113. Smith, C. A., D. W. Organ, J. P. Near. 1983. Organizational citizenship behavior: Its nature and antecedents. J.Appl.Psych. 68 653-663.

114. Shamir, B. and Lapidot, Y. 2003.Trust in Organizational Superiors: Systemic and Collective Considerations. Organization Studies 24(3): 463-491

115. Straiter, K. (The Effects of Supervisors' Trust of Subordinates and their Organization on Job Satisfaction and Organizational Commitment. International Journal of Leadership Studies, Vol. 1 Iss. 1, 2005, pp. 86101

116. Singh, U. \& Srivastava, K.B.L. (2009).Interpersonal Trust and organizational citizenship behavior. National Academy of Psychology (NAOP) India Psychological Studies 54:65-76

117. Schindler, P. L., \& Thomas, C. C. (1993). The structure of interpersonal trust in the workplace. Psychological Reports, 73, 563-573.

118. Tan, H. H., \& Tan, C. S. F. (2000). Toward the differentiation of trust in supervisor and trust in organization. Genetic, Social, and General Psychology Monographs, 126, 241-260.

119. Tsui, A.S., Pearce, J.L., Porter, and L.W. \& Tripoli, A.M. (1997) Alternative approaches to the employeeorganization relationship: Does investment in employees pay off? Academy of Management Journal 1997, Vol. 40. No. 5. 1089-1121.

120. Tyler, T.R. (2003), “Trust within organisations", Personnel Review, Vol. 32 No. 5, pp. 556-68.

121. Tyler. T. R. 1990. Why people obey the law. New Haven, CT: Yale University Press. 
122. Watson Wyatt (2002). Weathering the storm: A study of employee attitudes and opinions. Retrieved October 5, 2009, from http://www.watsonwyatt.com/research/resrender.asp?id=W-557\&page=1

123. Wat, D. and Shaffer, M.A. (2005) Equity and relationship quality influences on organizational citizenship behaviors: The mediating role of trust in the supervisor and empowerment. Personnel Review Volume: 34 Issue: 4 Page: 406 - 422

124. Wong, Y., Ngo, H., \& Wong, C. (2006). Perceived organizational justice, trust, and OCB: A study of Chinese workers in joint ventures and state-owned enterprises. Journal of World Business, 41, 344-355.

125. Wageman, R. (2001).The meaning of interdependence. In M. E. Turner (Ed.), Groups at work: Theory and research (pp. 197-217). Mahwah, NJ: Erlbaum.

126. Webb, W. M., \& Worchel, P. (1986). Trust and distrust. In S. Worchel \& W. G. Austin (Eds.), Psychology of intergroup relations (pp. 213-228). Chicago: Nelson-Hall.

127. Williamson, O. (1975), Markets and Hierarchies: Analysis and Antitrust Implications, A Study in the Economics of Internal Organisation, Free Press, New York, NY.

128. Yang, J. (2005). The role of Trust in organizationas: Do Foci and Bases matter? Louisiana State University, Doctor of Philosophy

129. Wong, Y., Wong, C., and Ngo, H.Y. (2002) Loyalty to supervisor and trust in supervisor of workers in Chinese joint ventures: a test of two competing models. International journal of HRM 13:6 S83-900 D Routledge

130. Zaheer, A., McEvily B., \& Perrone, V. 1998. Does trust matter? Exploring the effects of interorganizational and interpersonal trust on performance? Organization Science, 9: 141- 159.

131. Zand, D. E. (1972). Trust and managerial problem solving. Administrative Science Quarterly, 17, 229-239.

132. Zucker. L. G. 1986. Production of trust: Institutional sources of economic structure 1840-1920. In B. M. Staw \& L. L, Cummings (Eds,), Research in organizational behavior, vol. 8: 53-111. Greenwich, CT: JAI Press. 
International Journal of Management \& Information Systems - Second Quarter 2010

Volume 14, Number 2

NOTES 